\title{
元素の特性を活用した反応開発と天然物合成への応用
}

\author{
斉藤竜男
}

\section{Reaction Development Utilizing the Features of Chemical Elements and Synthesis of Marine Natural Products}

\author{
Tatsuo Saito ${ }^{\dagger}$ \\ Graduate School of Pharmaceutical Sciences, The University of Tokyo; \\ 7-3-1 Hongo, Bunkyo-ku, Tokyo 113-0033, Japan.
}

(Received June 1, 2018)

\begin{abstract}
Marine natural products and biologically active compounds often contain cyclic ether units. Thus, regio- and stereoselective construction of these structures has long been a topic of interest in organic synthesis. This review summarizes new synthetic approaches to polycyclic ether natural products utilizing the features of chemical elements.
\end{abstract}

Key words_—rhenium catalysis; 1,3-transposition; polyether; maitotoxin; gold catalysis

\section{はじめに}

生理活性を有する天然物や医薬品, 機能性分子を 効率的に構築する方法論の開発は有機合成化学にお ける重要な課題の 1 つである．複雑な構造を持つ天 然有機化合物を効率的に合成するためにはその構造 を理解するだけでなく，用いる反応の性質，特徵を 元素レベルで理解することが重要である。本総説で はポリエーテル系天然物の合成に焦点を当て，元素 の特性を活用した反応開発と合成例について概説す る.

レニウム触媒を用いたアリルアルコールの位置及 び立体選択的転位反応の開発

官能基の直接的な転位反応は，多段階の操作を必 要とせず，入手容易な前駆体から単一の操作で入手 困難な異性体へと変換可能であることから複雑な有 機化合物に対する強力な合成戦略である。中でも, アリルアルコールの $[1,3]$-転位反応は古くから知 られている代表的な転位反応の 1 つで，様々な金属 触媒で進行することが知られている (Fig. 1). 1) し かし，そのオキソ金属錯体の多くは(1)高温条件にお

東京大学大学院薬学系研究科（广113-0033 東京都文京 区本郷 7-3-1)

現所属: ‘東京農業大学生命科学部分子生命化学科 （干156-8502 東京都世田谷区桜丘 1-1-1) e-mail: ts206791@ nodai.ac.jp 本総説は, 平成 29 年度日本薬学会関東支部奨励賞の受 賞を記念して記述したものである.
いて高い触媒活性を示す，(2)転位反応と競合してア リル位の酸化反応なども引き起こす，ことから精密 有機合成への利用は限定的である。一方レニウム は，反応性及び化学選択性の点で優れており，周辺 元素のクロム，モリブデン，タングステン，バナジ ウムなどと比べ，酸化力が低く，低温において高い 転位反応性を有している。

しかしながら 1990 年代に盛んに研究されたもの の, ${ }^{2-4)}$ 天然物など複雑な分子に合成利用された例 は少ない，その理由として，転位反応が可逆的であ るため，位置選択性の制御が難しく，第一級アリル アルコールの転位における立体選択性も欠如してい ることが挙げられる，位置及び立体選択性の制御が 可能になれば，高酸化度複雑分子の効率的かつ実用 的な合成手法として期待されることから筆者はこの 課題解決に着手した，筆者は本転位反応に用いる酸 化レニウムが酸触媒としても機能する特性に着目 し，隣接する水酸基を足がかりに，アセタール若し くはケタールで捕捉することができれば，その水酸 基の立体情報を転写した 1,3-syn ジアステレオマー を優先して得られるものと期待した.

実際に二級水酸基を有する 1 級アリルアルコール 1 に対し，レニウム触媒のみを作用させると，予想 通り 60\%収率， $3: 2$ のジアステレオマー比と，低 い位置及び立体選択性で得られた。 そこにベンズア ルデヒドジメチルアセタール存在下同様の反応を行 


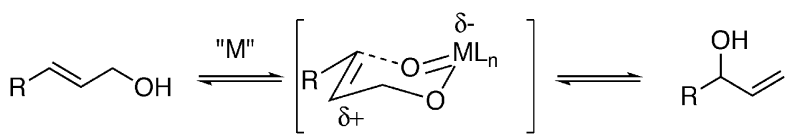

Fig. 1. Transposition of Allylic Alcohol<smiles>OC/C=C/CC(O)C1CCCCC1</smiles>

1

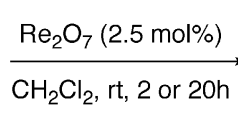

$\mathrm{CH}_{2} \mathrm{Cl}_{2}$, rt, 2 or $2 \mathrm{Oh}$

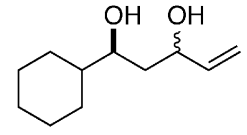

2 $60 \%$ conversion, ds 3:2

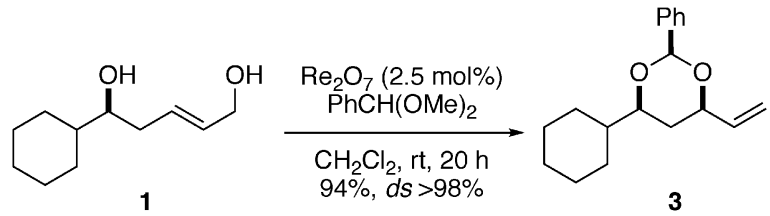

Scheme 1. Re-catalyzed Transposition of $\mathbf{1}$

うと, 転位成績体のアセタール保護体 $\mathbf{3}$ が単一生成 物で得られてきた。 反応条件の精査より，ジオール アセタールのジアステレオ混合物は短時間で形成さ れ，その後 1,3-syn アセタール（3）への平衡は遅 いことが明らかになった（Scheme 1).

購入容易な種々のレニウム触媒と反応時間の影響 について精査したところ，メチルトリオキソレニウ 厶 $(\mathrm{MTO}), \mathrm{Ph}_{3} \mathrm{SiReO}_{3}, \quad \mathrm{Re}_{2} \mathrm{O}_{7}$ は室温下 3 時間以 内で転位反応，アセタール形成は完結しており， MTO は予想通り低い反応性を示した（Table 1).

そこで最もジアステレオ選択性のよい結果を与え た $\mathrm{Re}_{2} \mathrm{O}_{7}$ を最適触媒と設定し，次に合成利用を志 向し，複雑な基質を用いた反応の適用範囲について 精查した（Table 2)。本反応条件においてベンジリ デンアセタールは分子内で転位可能で目的物を与え (1a)，脱保護の工程を必要とせずシリル基の除去が 同時に進行した（1b)。またアミン存在下でもその 相対立体配置に影響はなく，高いジアステレオ選択 性で化合物が得られた（1c, 1d）。さらに PMB や TBDPS など酸に低耐性の保護基は容易に脱保護さ れ，アセタール保護基へ変換可能であった $(\mathbf{1 g}-\mathbf{j})$. ポリオールモデル化合物だけでなく，ポリエーテル 系天然物のモデル化合物合成でも高いジアステレオ 選択性で得られることが明らかになった（1e, 1f， 1k)。以上のように，レニウムの高い転位反応性の 陰で目立たなかつた酸触媒としての機能を活用する ことで長年の課題であつた転位選択性の獲得につな
がつた.5

\section{マイトトキシン疎水性部の合成研究}

メキシコ湾で多発する赤潮毒の原因種である渦鞭 毛藻 Karenia brevis（Gymnodinum breve）が生産 する毒ブレベトキシン B が 1981 年，中西らによっ て海洋産ポリエーテル系天然物として初めて単離, 構造決定されて以来, ${ }^{6,7)}$ 多くの類縁天然物が単離, 構造決定されている. ${ }^{8-10)}$

これら天然物は，5-9 員環エーテルが梯子状に trans-縮環したほかに類を見ない特異な化学構造を 有しており，また生体内のイオンチャネルに結合 し，強い神経毒性を示すなど，顕著な生物活性を示 す. ${ }^{11)}$ 中でも, 1993 年, 村田, 安元らによって洞鞭 毛藻 Gambierdiscus toxicus からシガテラ中毒の原 因物質として単離されたマイトトキシン（MTX, 5, Fig. 2： $\mathrm{P}-\mathrm{F}^{\prime}$ 環部の夕記載）は，タンパク質，核酸 及び多糖類などの生体高分子を除けば，天然物では 最大の分子量 (3422) を有している. さらに，カル シウムイオンの透過性増強作用を有する, 非夕ンパ ク質化合物としては最強のマウス致死毒性（ $\mathrm{LD}_{50}$ $=50 \mathrm{ng} / \mathrm{kg}$ ）を示し，その毒性はフグ毒テトロドト キシンの 200 倍に相当する. MTX（5）の構造は, エーテル環の核間位にメチル基を多く含む疎水性部

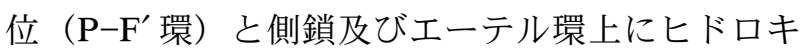
シ基，スルホン酸塩が集中する親水性部位（A-O 環）に大きく分けることができる. ${ }^{12-15)}$ それぞれの 部位の活性発現への役割は異なることが予想され， 各部位の化学合成による供給は作用機序の解明にも 極めて重要である。 その特異な化学構造と強い生物 活性から，国内外の研究グループ（Nicolaou ら, 16-20) 大石ら, ${ }^{21-24)}$ 中田ら, ${ }^{25-27)}$ ) によってその合 成研究が行われている。これまでに筆者らは MTX 疎水性部に関し，既にWXYZA' 環部及び側鎖を有 する $\mathrm{C}^{\prime} \mathrm{D}^{\prime} \mathrm{E}^{\prime} \mathrm{F}^{\prime}$ 環部の合成を報告しており, ${ }^{25-27)}$ 残 された課題は唯一の 8 員環エーテル $\mathrm{B}^{\prime}$ 環部の合成 である.

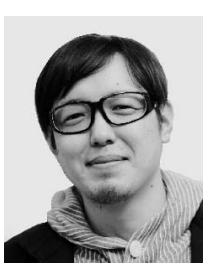

斉藤竜男
2009 年東京理科大学大学院理学研究科 博士後期課程修了後, 米国 UC サンタ バーバラ博士研究員, 2011 年理化学研 究所基礎科学特別研究員, 2013 年東京 大学大学院薬学系研究科助教を経て, 2018 年より東京農業大学生命科学部分 子生命化学科助教。専門は天然物合成 化学, 有機合成化学. 
Table 1. Influence of the Catalyst and Reaction Time

\begin{tabular}{|c|c|c|c|c|}
\hline Entry & Catalyst (mol\%) & Time & Conversion $^{\mathrm{a}}$ & $3: 4^{\mathrm{a}}$ \\
\hline 1 & $\mathrm{MeReO}_{3}$ (5) & $40 \mathrm{~min}$ & $\sim 45 \%$ & $36: 64$ \\
\hline 2 & $\mathrm{MeReO}_{3}(5)$ & $3 \mathrm{~h}$ & complete & $40: 60$ \\
\hline 3 & $\mathrm{MeReO}_{3}$ & $20 \mathrm{~h}$ & complete & $63: 37$ \\
\hline 4 & $\mathrm{Ph}_{3} \mathrm{SiOReO}_{3}$ & $40 \mathrm{~min}$ & complete & $65: 35$ \\
\hline 5 & $\mathrm{Ph}_{3} \mathrm{SiOReO}_{3}$ & $3 \mathrm{~h}$ & complete & $87: 13$ \\
\hline 6 & $\mathrm{Ph}_{3} \mathrm{SiOReO}_{3}$ & $20 \mathrm{~h}$ & complete & $96: 4$ \\
\hline 7 & $\mathrm{Re}_{2} \mathrm{O}_{7}$ & $40 \mathrm{~min}$ & complete & $80: 20$ \\
\hline 8 & $\mathrm{Re}_{2} \mathrm{O}_{7}(2.5)$ & $3 \mathrm{~h}$ & complete & $91: 9$ \\
\hline 9 & $\mathrm{Re}_{2} \mathrm{O}_{7}(2.5)$ & $20 \mathrm{~h}$ & complete & $>98: 2$ \\
\hline
\end{tabular}

a Measured by $500 \mathrm{MHz}$ NMR spectroscopy using a crude mixture of products.

B' 環はマイトトキシン合成において最難関部位 の1つである. 両セグメントの合成の基盤となつた ヨウ化サマリウムを用いた還元的環化反応では 8 員 環を立体選択的に構築困難であることから，筆者ら は直線的な合成戦略ではなく, Nicolaou ら, 中田 らのブレベトキシン B の合成戦略と同じく，Wittig カップリングを鍵とする収束的合成戦略による構築 を目指した（Fig. 3). ${ }^{28,29)}$ しかしながらイリド調製 の際に用いる強塩基により，望むカップリング体 $\mathbf{8}$ はごく少量しか得られず，アルデヒド基から望まな い逆マイケル反応が進行した化合物 9 を与える結果 となった。 そこで本結果を踏まえ，収束部位を変更 し，ビニルハライド 12 と 13 より誘導したアルキル ボランとの温和な条件で行う鈴木一宮浦クロスカッ プリング30)により結合し， $O, S$-アセタール 11 の還 元による $\mathrm{B}^{\prime}$ 環の構築を目指し，2 環性モデル化合 物を用いて検討することとした（Fig. 4).

\section{$\mathbf{C}^{\prime} \mathbf{D}^{\prime}$ 環部 12 の合成}

2-デオキシ-D-リボースを出発原料としてヨウ化 サマリウムを用いた還元的環化反応により合成した 既知の 2 環性化合物 140-32) よりエステルの還元, 続くジオールの保護により，ジベンジルエーテル 15 へと導いた [Scheme 2(A)]. ベンジリデンアセ タールの脱保護，二級アルコールの PMB 保護を経 て一級アルコール 16 へと誘導した。 16 に対し, TPAP 酸化, ついでジヨードオレフィン 17 へと導 いたのち，酢酸中亜鉛-銅カップルを作用させるこ
とで33) 望む左セグメントである（Z)-ビニルヨージ ド 12 を調製した。

\section{$\mathbf{Z A}^{\prime}$ 環部 13 の合成}

同じく 2-デオキシ-D-リボースを出発原料として 文献既知の方法で合成した一級アルコール 1834) に 対し，酸化，Wittig 反応，続く還元によりアリルア ルコール 20 を合成した [Scheme 2(B) ]。 MCPBA によるエポキシ化は立体選択的に進行し，エポキシ アルコール 21 を単一生成物として与えた。 その後 酸化，Wittig 反応，TBS 基の除去により導いたビ ニルエポキシド 22 を Nicolaou らの 6 員環エーテル 合成法 ${ }^{34)}$ により 2 環性化合物 19 を高収率で合成し た。その後オゾン酸化により一炭素減炭し，アルデ ヒドにした後，アルコールへの還元，ヨウ素化，脱 離反応により，エキソメチレン体 13 へと導いた。

\section{鈴木一宮浦カップリングによる収束合成}

$\mathrm{ZA}^{\prime}$ 環部 13 に対し 9-BBN を作用させヒドロホウ 素化ののち, 別途調製した $\mathrm{C}^{\prime} \mathrm{D}^{\prime}$ 環部 $(Z)$-ビニル ヨージド 12 をパラジウム触媒存在下加えることで 鈴木一宮浦カップリングが収率よく進行し，25を与 えた（Scheme 3)．その後 PMB 基の除去，酸化を 経てケトン 26 へ導き, 混合アセタール化反応の 検討を行った。 Zn (OTf $)_{2}$ 存在下, エタンチオール を短時間作用させることでジチオアセタール 27 が 得られた。 なお，同条件下で長時間反応に付すと， $C^{\prime}$ 環が開環した 29 が多く副生する結果となった. これは過剩量の $\mathrm{Zn}(\mathrm{OTf})_{2}$ が $\mathrm{C}^{\prime}$ 環酸素原子に配位 
Table 2. Scope of the Re-catalyzed Transposition/Acetalization with Complex Substrates ${ }^{\text {a }}$

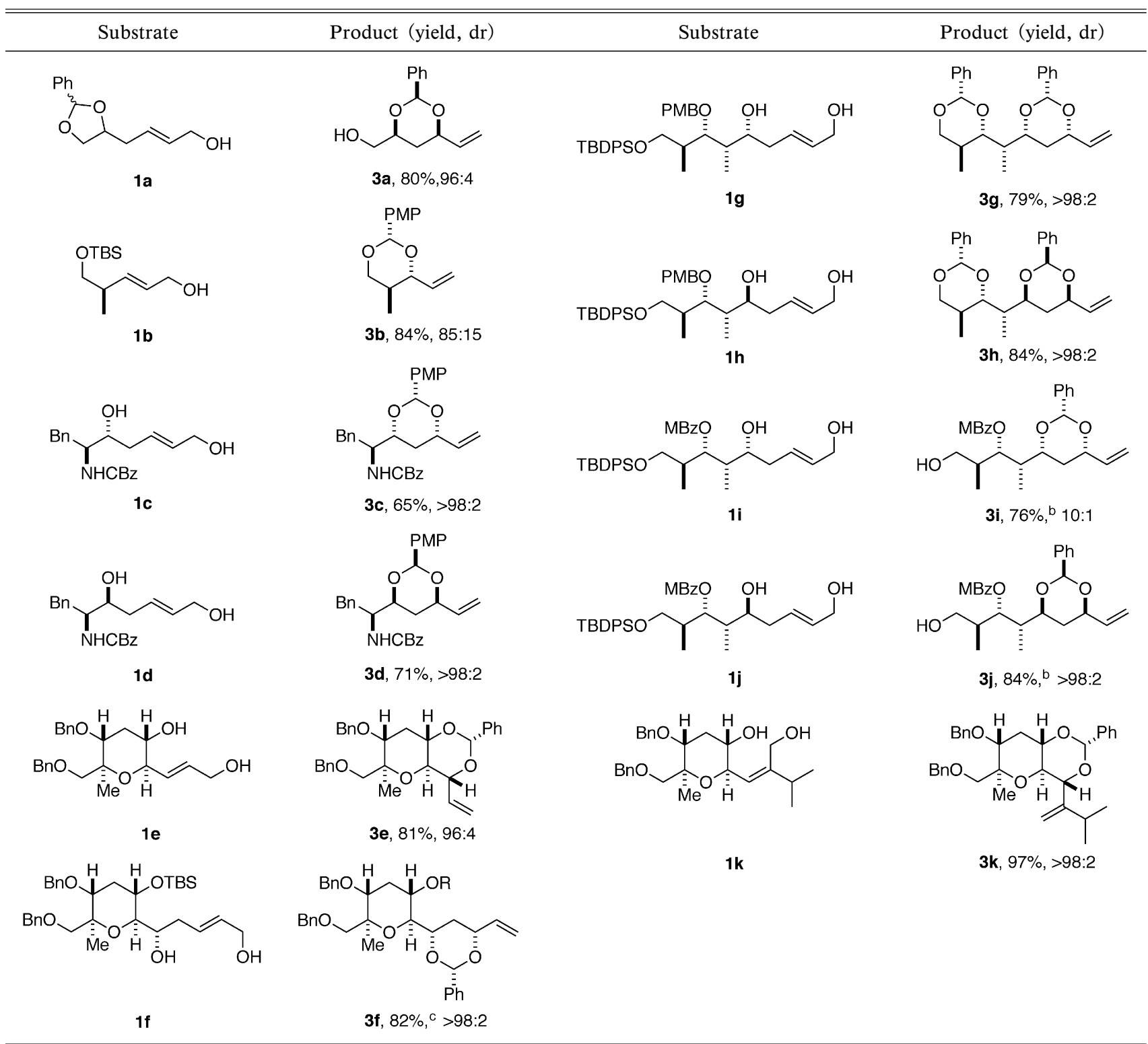

a Reactions were performed in $\mathrm{CH}_{2} \mathrm{Cl}_{2}(\sim 0.2 \mathrm{M})$ with $2.5 \mathrm{~mol} \%$ of $\mathrm{Re}_{2} \mathrm{O}_{7}$ and 2.0 eq of $\mathrm{PhCH}(\mathrm{OMe})_{2}$ or $4-\mathrm{MeOPhCH}(\mathrm{OMe}){ }_{2}$; dr is determined by $500 \mathrm{MHz}$ ${ }^{1} \mathrm{H}$ NMR. ${ }^{\mathrm{b}}$ Overall yield after treatment with TBAF. ${ }^{\mathrm{c}} \mathrm{R}=\mathrm{H} / \mathrm{R}=\mathrm{TBS} 5.3: 1$.

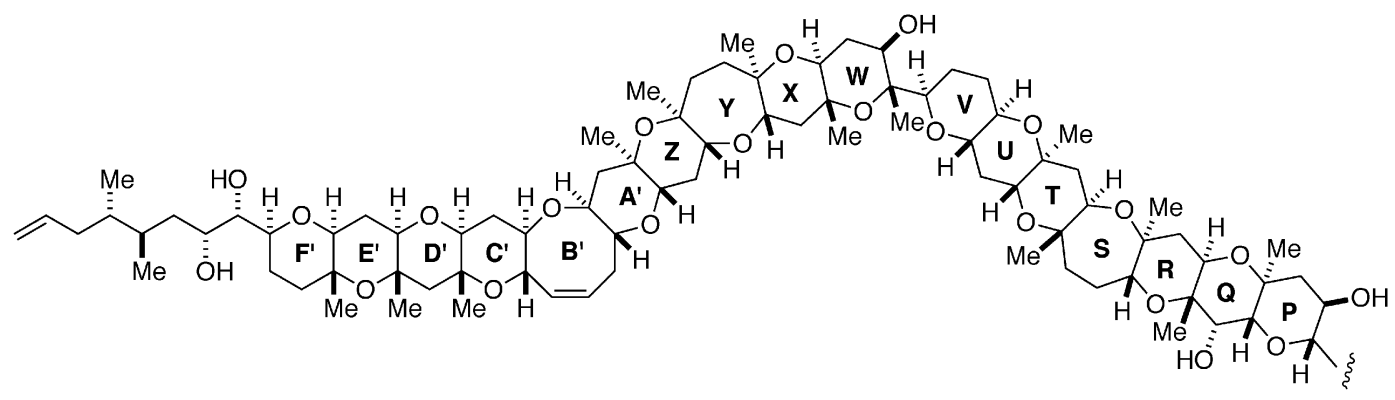

Fig. 2. Hydrophobic Part of Maitotoxin (5) 


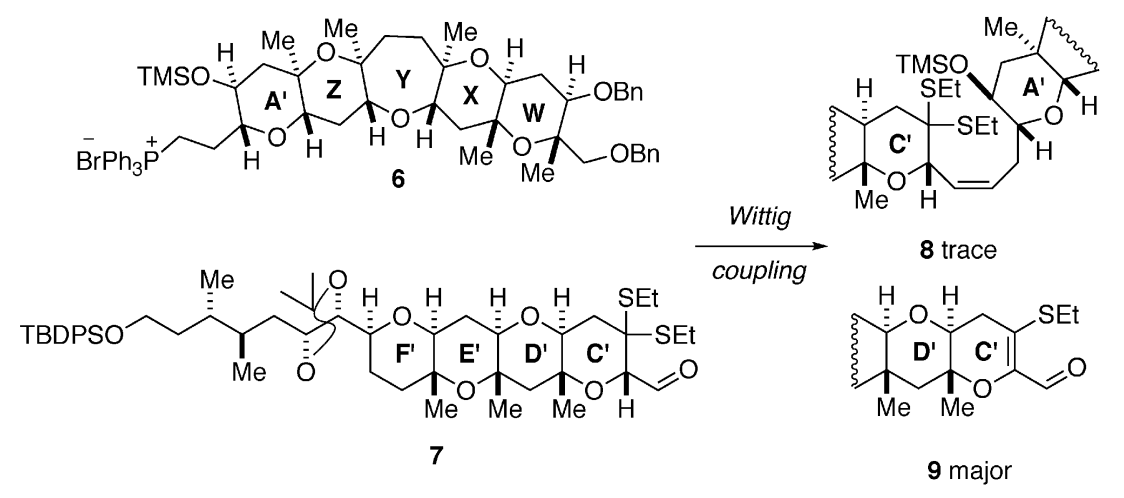

Fig. 3. Attempted Wittig Coupling of Fragments 6 and 7 for MTX B'-Ring Construction
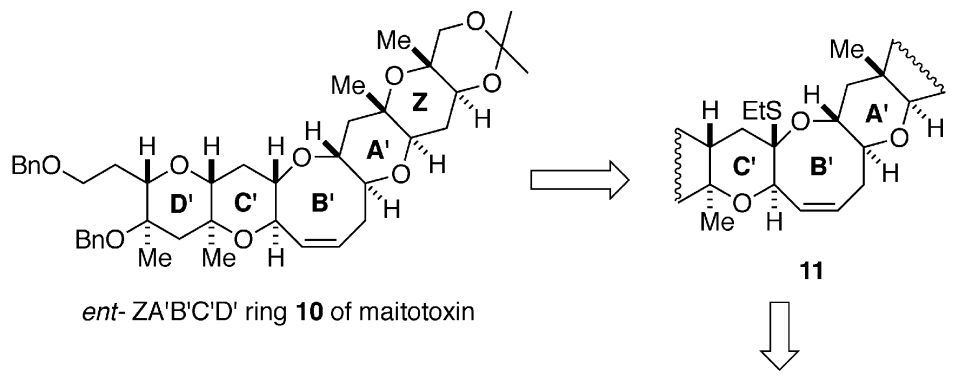

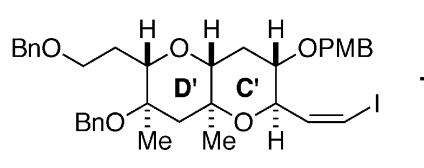

12

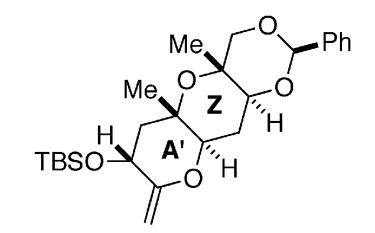

13

Fig. 4. Synthetic Plan for MTX B'-Ring Construction

し，チオアセタールのエカトリアル位スルフィドが

$C^{\prime}$ 環の開環を伴う分子内環化を誘導し，その後三 員環チオニウムカチオンに対し溶媒量のエタンチ オールが付加したためだと考えられる. 得られた所 望のジチオアセタール 27 をアセトナイド保護,

TBS 除去, $O, S$-混合アセタール化を経て 11 へと導 いた後, トリフェニルスズヒドリドにより還元する ことで $\mathrm{B}^{\prime}$ 環 $\mathbf{1 0}$ の合成を達成した。 得られた化合物 の立体構造について各種 NMR を解析したところ,

望むsyn-trans の立体配座で合成されたことを確認

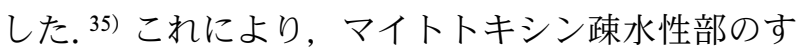
べての環構築法を確立した.

\section{金触媒による位置選択的エーテル環構築法の開発}

環状エーテル骨格は，生理活性を有する天然物や 医薬品, 機能性分子で重要な構造単位である. 先述 のマイトトキシンのような海洋産ポリエーテル系天 然物の効率的合成には直截的な環化反応の開発は重
要であり, エーテル環構造の位置選択的及び化学選 択的構築は, 有機合成化学分野において今なお関心 を集めている.

近年，金触媒のアルキン $\pi$ 電子との高い親和性 を活かしたへテロ環合成は急速に研究が進み, 複雑 な構造を構築する重要な手法となりつつある. ${ }^{36,37)}$ 炭素-炭素三重結合を介したアルコールの触媒的分 子内付加は, 環状エーテルの構築に有効であると期 待できるが, 中員環エーテル合成への応用は,

1）エンタルピー及びエントロピー的に不利である こと，2）三重結合への閉環における低い位置選択 性であることからいまだ一般性の高い手法は確立さ れていない。 そのような背景から筆者は海洋産ポリ エーテル系天然物の迅速合成を志向し，アルキニル アルコールの金触媒による分子内環化反応をアルキ ンの電子的及び/又は立体的性質の影響に焦点を当 てた 6-exo/7-endo 選択性について精査した 


\section{A: Synthesis of the C'D'-ring fragment 12}

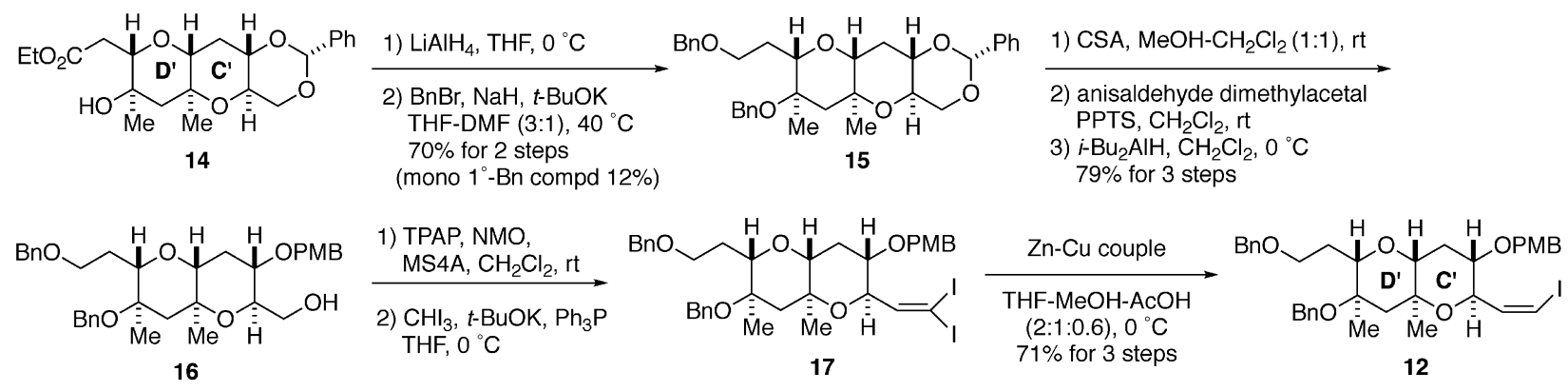

\section{B: Synthesis of the $\mathrm{ZA}^{\prime}$-ring fragment 13}
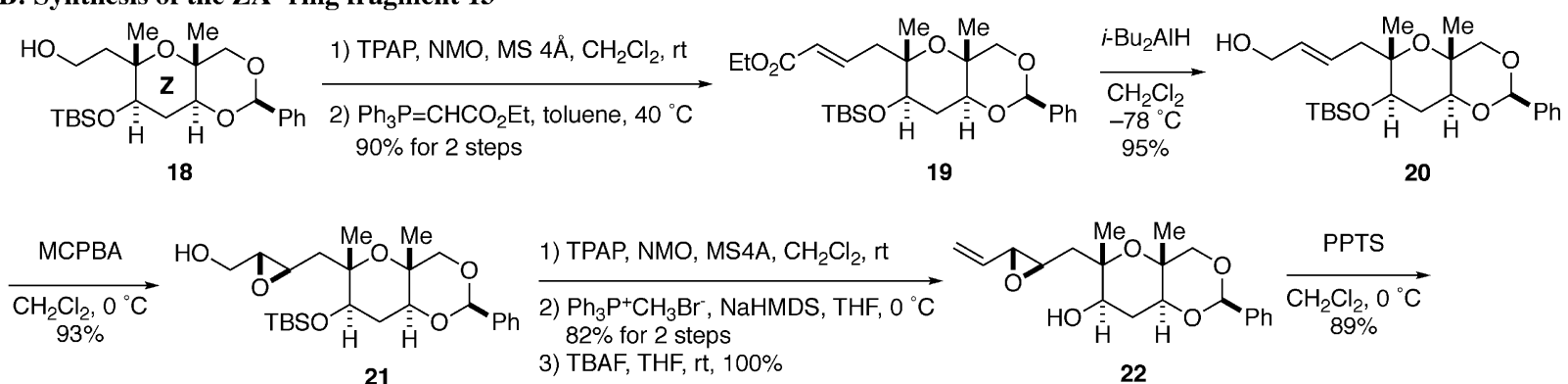

3) TBAF, THF, rt, $100 \%$

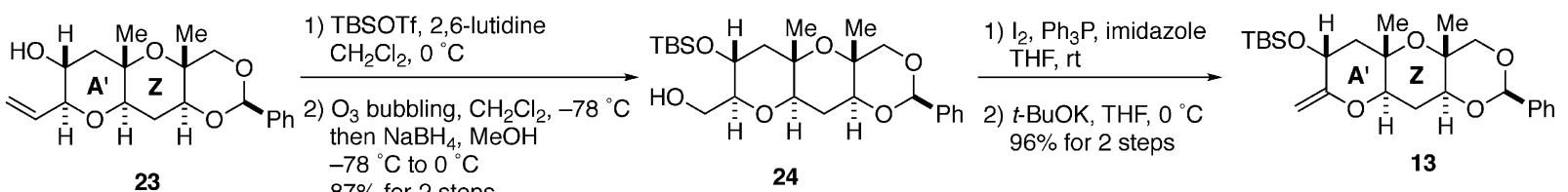

Scheme 2. Synthesis of Both Fragments $\mathbf{1 2}$ and $\mathbf{1 3}$
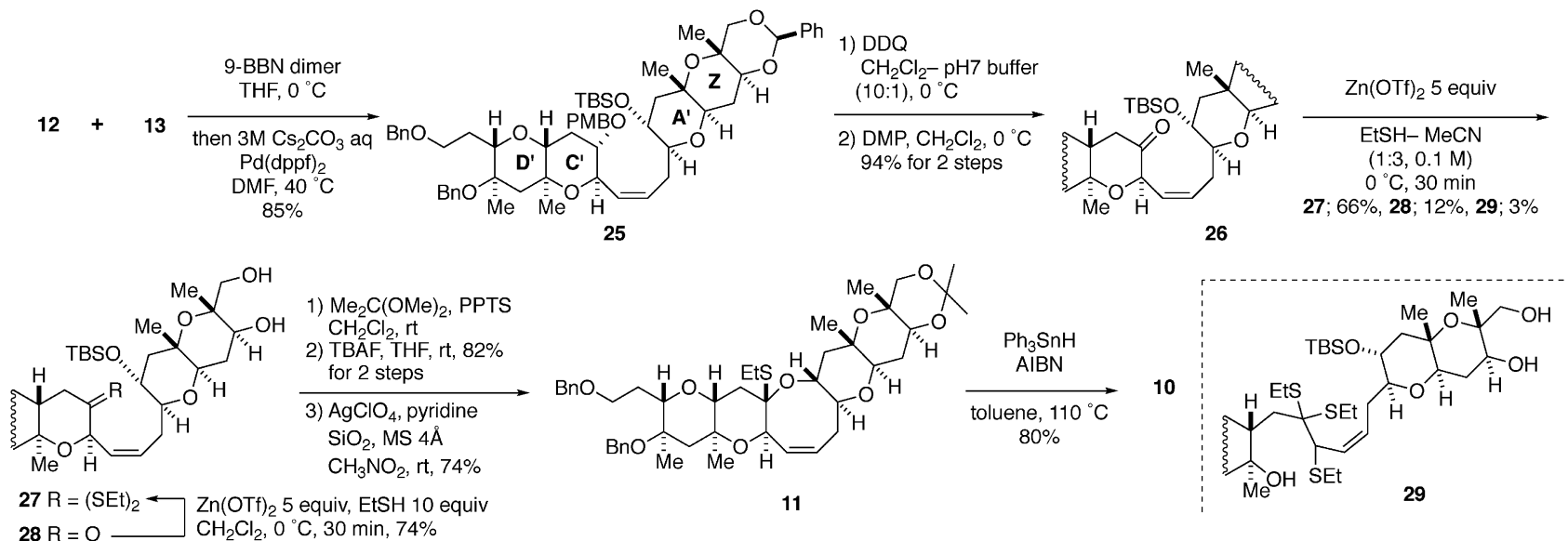

Scheme 3. Synthesis of ent-ZA' $\mathrm{B}^{\prime} \mathrm{C}^{\prime} \mathrm{D}^{\prime}$-Ring $\mathbf{1 3}$ of MTX

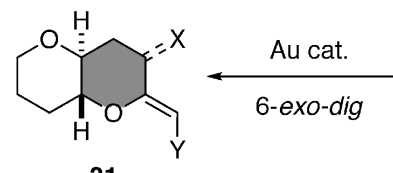

31<smiles>[Y]C#CC([X])CC1OCCCC1O</smiles>

30
32

$X=$ methylene, ether, carbonyl $\mathrm{Y}=\mathrm{EDG}, \mathrm{H}, \mathrm{EWG}$

Scheme 4. Regioselectivity in the Intramolecular Cyclization of Alkynol 30 


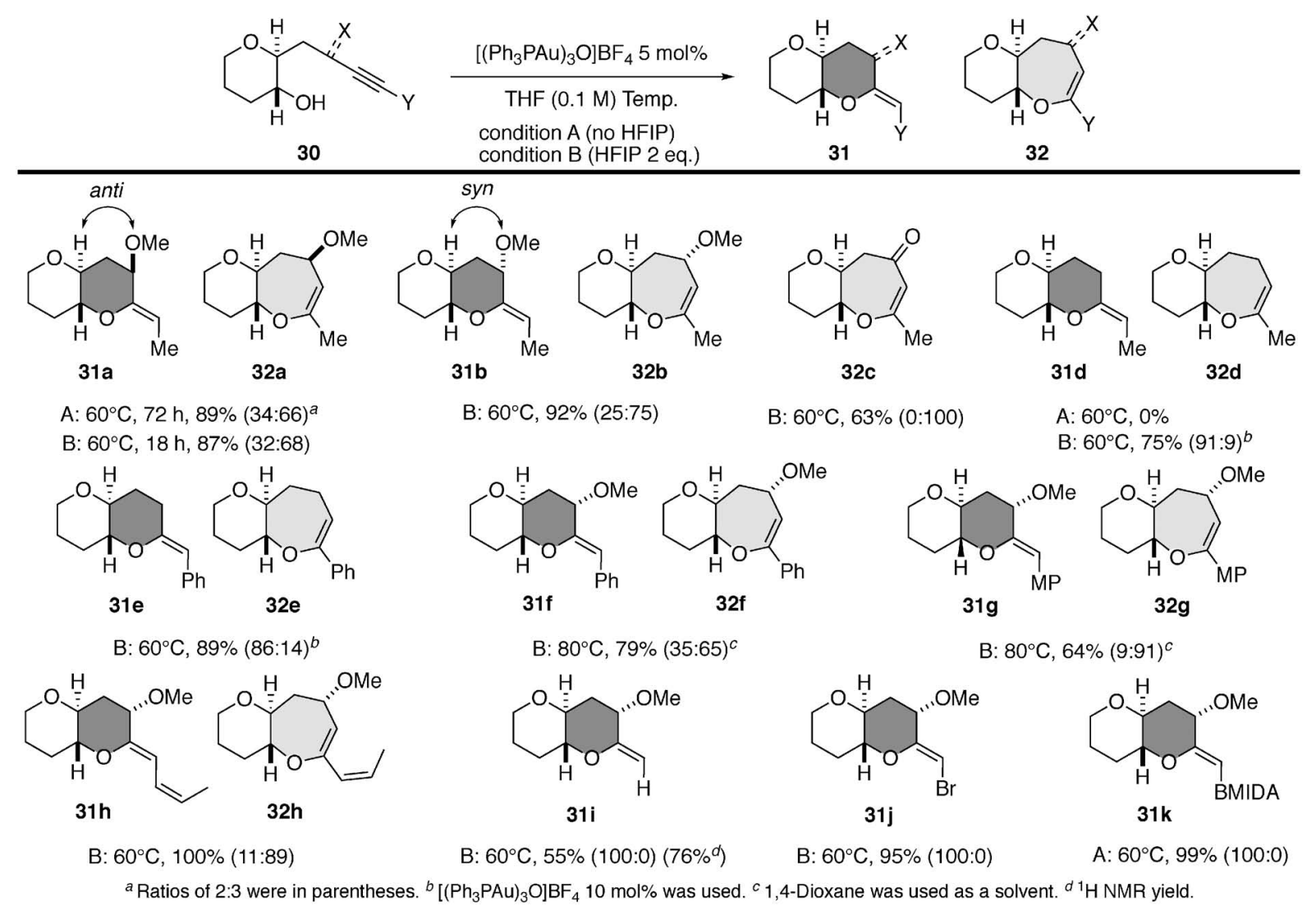

Fig. 5. Gold-catalyzed Intramolecular Cyclization of Alkynol

(Scheme 4).

金触媒反応の進行には大きく分けて(1)金触媒によ る不飽和結合の活性化，(2)求核剤の求核付加による 結合形成, (3)プロトン化による金触媒の再生（protodeauration）の 3 段階がある. 従来, 反応進行に は(1)と(2)が重要で, 最終段階の protodeauration は 非常に早い反応であると考えられていた。 そのため 金触媒反応の反応機構解析においてはプロトン移動 として重要視されていなかった. しかし近年, 反応 中間体である有機金化合物が単離される例が報告さ れていることから, ${ }^{38-41)}$ protodeauration 段階は無 視できるほど容易ではなく反応に大きく関与してい ると推察し, プロトン源を添加することで反応の加 速効果を期待した.

ポリエーテルモデル化合物 30a を基質とし, 詳細 な条件検討を行ったところ, THF 中, 触媒として $\left[\left(\mathrm{Ph}_{3} \mathrm{PAu}\right)_{3} \mathrm{O}\right] \mathrm{BF}_{4}$, 添加剂として 1,1,1,3,3,3-hexafluoro-2-propanol（HFIP）を用いた場合，目的の 環化体が収率よく得られることを見い出した。本条 件を基に, 基質のプロパルギル位の官能基 X と, アルキン末端の置換基 Y の環化選択性に対する影
響を精査し，環化反応の詳細について解析した (Fig. 5).

$\mathrm{X}$ が $\mathrm{MeO}$ 基（30a, 30b）の場合，7-endo 環化が 優先した。 一方, 30c $(\mathrm{X}=\mathrm{O})$ では, 電子的な影響 により Michael 型付加が優先し， 7 員環のみが選択 的に得られた。 また $\mathrm{CH}_{2}$ に変換すると（30d, 30e) 選択性が逆転し 6-exo 環化が優先した. 以上のこと から，プロパルギル位の酸素官能基の有無や酸化度 の変化により, 環化方向の制御が可能であることが 明らかになった. 次にポリエーテル環合成を志向し, $\mathrm{X}=\mathrm{OMe}$ に固定し, 置換基 $\mathrm{Y}$ の効果を調べた. $\mathrm{Y}=\mathrm{H}, \mathrm{Br}, \quad N$-methyliminodiacetic acid boronate (BMIDA) (30i-k) の場合では 6 員環が, $p$-methoxyphenyl（MP）基や cis-propenyl 基を有する基質 $(30 \mathrm{~g}, 30 \mathrm{~h})$ では 7-endo 環化が優先した。このよう に末端置換基により，アルキンの 2 つ炭素の電子 的性質を差別化することで 6-exo, 7-endo 環化を制 御することができる，つまり，電子求引性の置換基 を導入することで 6-exo 環化，より電子供与性の高 い置換基を導入することで 7-endo 環化選択性を向 上させることが明らかになった。 


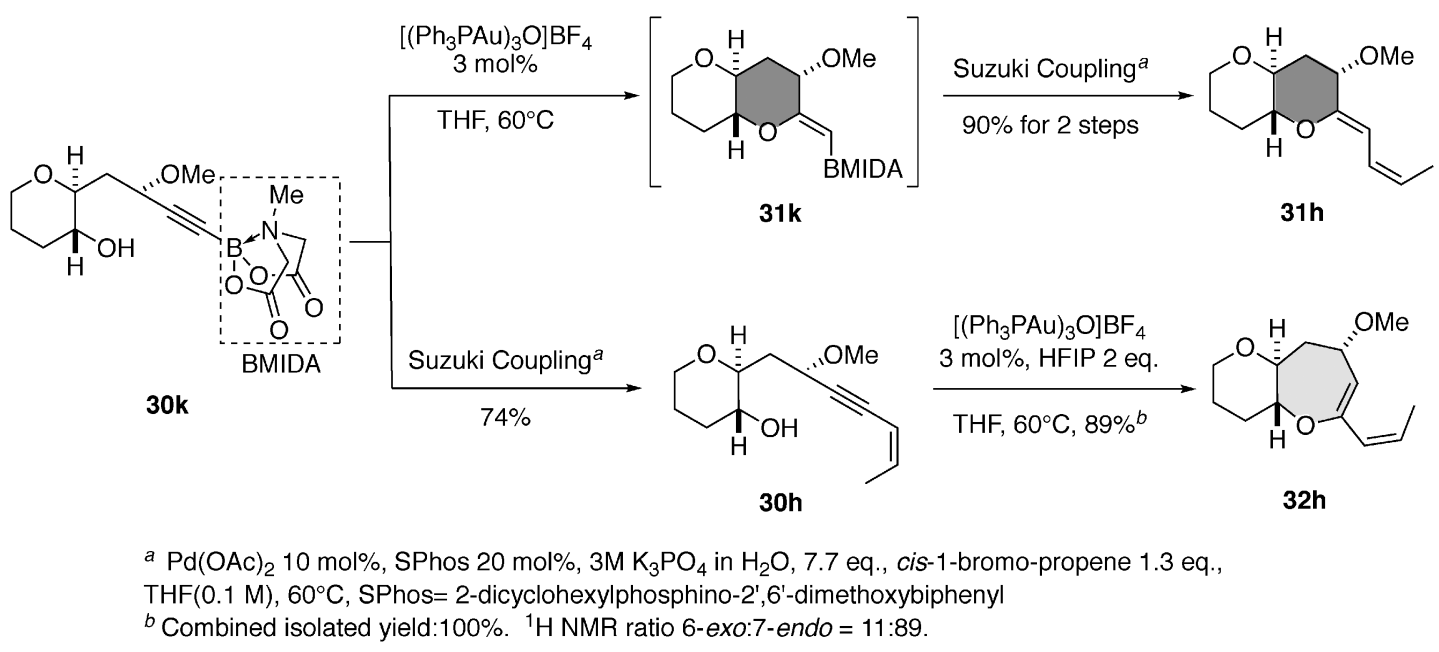

Scheme 5. Synthetic Application of Sequential Cyclization/Cross-coupling and Cross-coupling/Cyclization Reaction

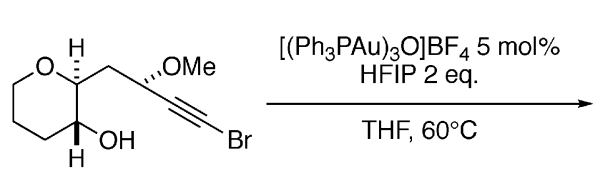

30j

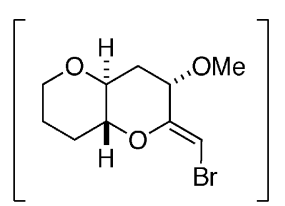

31j

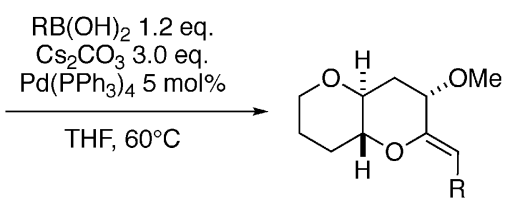

$\mathrm{R}=\mathrm{Ph}: \mathbf{3 1 f} 86 \%$ $R=M P: 31976 \%$

Scheme 6. One-pot Syntheses of $\mathbf{3 1}$ from Alkynol 30j

さらにこれら置換基による反応性の差異を活用 し，本環化反応とクロスカップリングとの連続反応 を設計することによる 6-6 縮環構造と 6-7 縮環構造 の選択的な作り分けが可能であった (Scheme 5). 末端に BMIDA を有する基質（30k）では，金触媒 を用いる環化反応で完全な位置選択性で 6-6 縮環構 造を与えた。その後，ボロン酸部位での鈴木一宮浦 カップリング反応を行うことにより, cis-propenyl 基を導入した縮環構造（31h）を立体選択的に 2 段 階ワンポットにて $90 \%$ の収率で得ることができ た．一方，先にクロスカップリング反応を行い，末 端にオレフィンを導入した（30h）後に，金触媒で の環化反応の条件に付すことで，6-7 縮環構造を有 するエーテル骨格 (32h) を選択的かつ効率的に合 成した.

またこの連続的環化一カップリング合成戦略は BMIDA だけでなく，末端に $\mathrm{Br}$ を持つ基質でも適 用可能であることが明らかになった。本基質では， カップリングパートナーとしてボロン酸を用いるこ とができるため, 先述の連続反応と相補的なもので あるという点で有用である (Scheme 6).
このようにアルキン部位周辺の電子的及び立体的 な構造変化によって選択性を制御できることが明ら かになった. ${ }^{42)}$ 現在本手法を用いたポリエーテル系 天然物の新しい合成戦略の検討を行っているところ である.

\section{おわりに}

このように筆者は元素の特性を理解し活用するこ とで, 短工程, 高効率的な新しい反応のデザインを 行い，ポリエーテル系天然物の合成へと展開した. 今後も有機化学を基盤とした元素の特性を生かした 反応開発を通して，ポリエーテル系天然物のみなら ず，合成困難な生理活性分子の合成を目指したい.

謝辞本研究は中田 忠先生（東京理科大学教 授/理化学研究所名誉研究員) のご指導の下遂行し たものです。その後袖岡幹子先生（理化学研究所主 任研究員）及び内山真伸先生（東京大学教授/理化 学研究所主任研究員）のご助言を得て，ようやく本 成果に至りました。研究室に加えて頂き，多大なる ご指導，ご支援賜りました諸先生方に厚く御礼申し 上げます。また本研究に取り組み，日々絶え間ない 
努力と創意工夫で切り拓いた久保田美央 修士，秋 本 楽 修士, 近藤正樹 学士に心より感謝いたしま す。さらに，有益なご助言を頂きました共同研究者 の皆様に厚く御礼申し上げます。本研究は文部科学 省科学研究費補助金及び東京生化学研究会, 薬学振 興会の研究助成によって行われたものです，併せて 感謝申し上げます。

利益相反＼cjkstart開示すべき利益相反はない.

\section{REFERENCES}

1) Bellemin-Laponnaz S., Le Ny J. P., $C . R$. Chimie, 5, 217-224 (2002).

2) Bellemin-Laponnaz S., Gisie H., Le Ny J. P., Osborn J. A., Angew. Chem., Int. Ed. Engl., 36, 976-978 (1997).

3) Bellemin-Laponnaz S., Le Ny J. P., Osborn J. A., Tetrahedron Lett., 41, 1549-1552 (2000).

4) Jacob J., Espenson J. H., Jensen J. H., Gordon M. S., Organometallics, 17, 1835-1840 (1998).

5) Herrmann A. T., Saito T., Stivala C. E., Tom J., Zakarian A., J. Am. Chem. Soc., 132, 5962-5963 (2010).

6) Lin Y.-Y., Risk M., Ray S. M., Van Engen D., Clardy J., Golik J., James J. C., Nakanishi K., J. Am. Chem. Soc., 103, 6773-6775 (1981).

7) Lee M. S., Repeta D. J., Nakanishi K., Zagorski M. G., J. Am. Chem. Soc., 108, 7855-7856 (1986).

8) Yasumoto T., Murata M., Chem. Rev., 93, 1897-1909 (1993).

9) Murata M., Yasumoto T., Nat. Prod. Rep., 17, 293-314 (2000) .

10) Yasumoto T., Chem. Rec., 3, 228-242 (2001).

11) Trainer V. L., Baden D. G., Catterall W. A., J. Biol. Chem., 269, 19904-19909 (1994) .

12) Murata M., Iwashita T., Yokoyama A., Sasaki M., Yasumoto T., J. Am. Chem. Soc., 114, 6594-6596 (1992).

13) Murata M., Naoki H., Iwashita T., Matsunaga S., Sasaki M., Yokoyama A., Yasumoto T., J. Am. Chem. Soc., 115, 2060-2062 (1993).

14) Murata M., Naoki H., Matsunaga S., Satake M., Yasumoto T., J. Am. Chem. Soc., 116,
7098-7107 (1994).

15) Satake M., Ishida S., Yasumoto T., Murata M., Utsumi H., Hinomoto T., J. Am. Chem. Soc., 117, 7019-7020 (1995).

16) Nicolaou K. C., Postema M. H. D., Yue E. W., Nadin A., J. Am. Chem, Soc., 118, 10335-10336 (1996).

17) Nicolaou K. C., Gelin C. F., Seo J. H., Huang Z., Umezawa T., J. Am. Chem. Soc., 132, 9900-9907 (2010).

18) Nicolaou K. C., Seo J. H., Nakamura T., Aversa R. J., J. Am. Chem. Soc., 133, 214219 (2011).

19) Nicolaou K. C., Baker T. M., Nakamura T., J. Am. Chem. Soc., 133, 220-226 (2011) .

20) Nicolaou K. C., Heretsch P., Nakamura T., Rudo A., Murata M., Konoki K., J. Am. Chem. Soc., 136, 16444-16451 (2014).

21) Oishi T., Hasegawa F., Torikai K., Konoki K., Matsumori N., Murata M., Org. Lett., 10, 3599-3602 (2008).

22) Kunitake M., Oshima T., Konoki K., Ebine M., Torikai K., Murata M., Oishi T., J. Org. Chem., 79, 4948-4962 (2014).

23) Onoue H., Baba T., Konoki K., Torikai K., Ebine M., Oishi T., Chem. Lett., 43, 19041906 (2014).

24) Osato N., Onoue H., Toma Y., Torikai K., Ebine M., Satake M., Oishi T., Chem. Lett., 47, 265-268 (2018).

25) Sakamoto Y., Matsuo G., Matsukura H., Nakata T., Org. Lett., 3, 2749-2752 (2001).

26) Morita M., Ishiyama S., Koshino H., Nakata T., Org. Lett., 10, 1675-1678 (2008).

27) Morita M., Haketa T., Koshino H., Nakata T., Org. Lett., 10, 1679-1682 (2008).

28) Nicolaou K. C., Rutjes F. P. J. T., Theodorakis E. A., Tiebes J., Sato M., Untersteller E., J. Am. Chem. Soc., 117, 10252-10263 (1995).

29) Matsuo G., Kawamura K., Hori N., Matsukura H., Nakata T., J. Am. Chem. Soc., 126, 14374-14376 (2004).

30) Miyaura N., Suzuki A., Chem. Rev., 95, 2457-2483 (1995).

31) Kadota I., Takamura H., Sato K., Ohno A., Matsuda K., Yamamoto Y., J. Am. Chem. Soc., 125, 46-47 (2003).

32) Kadota I., Takamura H., Sato K., Ohno A., 
Matsuda K., Satake M., Yamamoto Y., J. Am. Chem. Soc., 125, 11893-11899 (2003).

33) Kadota I., Ueno H., Ohno A., Yamamoto Y., Tetrahedron Lett., 44, 8645-8647 (2003).

34) Nicolaou K. C., Nugiel D. A., Couladouros E., Hwang C.-K., Tetrahedron, 46, 4517-4552 (1990).

35) Saito T., Morita M., Koshino H., Sodeoka M., Nakata T., Org. Lett., 19, 3203-3206 (2017).

36) "Gold Catalysis: An Homogeneous Approach,', ed. by Toste F. D., Michelet V., Imperial College Press, London, 2014.

37) Dorel R., Echavarren A. M., Chem. Rev., 115, 9028-9072 (2015).
38) Liu L.-P., Xu B., Mashuta M. S., Hammond G. B., J. Am. Chem. Soc., 130, 17642-17643 (2008).

39) Shi Y., Ramgren S. D., Blum S. A., Organometallics, 28, 1275-1277 (2009).

40) LaLonde R. L., Brenzovich W. E. Jr., Benitez D., Tkatchouk E., Kelley K., Goddard W. A., Toste F. D., Chem. Sci., 1, 226-233 (2010).

41) Döpp R., Lothschütz C., Wurm T., Pernpointner M., Keller S., Rominger F., Hashmi A. S. K., Organometallics, 30, 5894-5903 (2011).

42) Kubota M., Saito T., Miyamoto K., Hirano K., Wang C., Uchiyama M., Chem. Pharm. Bull., 64, 845-855 (2016). 